\title{
Recovery of Valuable Metals from Nickel Smelting Slag Based on Reduction and Sulfurization Modification
}

\author{
Wei Sun, Xiong Li, Runqing Liu * ${ }^{\mathbb{C}}$, Qilin Zhai and Jie Li \\ School of Minerals Processing and Bioengineering, Central South University, Changsha 410083, China; \\ sunmenghu@csu.edu.cn (W.S.); csulx2015@163.com (X.L.); zhaiqilinxue@163.com (Q.Z.); \\ lijie2511@csu.edu.cn (J.L.) \\ * Correspondence: liurunqing@126.com; Tel.: +86-0731-88830482; Fax: +86-0731-88660477
}

check for

updates

Citation: Sun, W.; Li, X.; Liu, R.; Zhai, Q.; Li, J. Recovery of Valuable Metals from Nickel Smelting Slag

Based on Reduction and Sulfurization Modification. Minerals 2021, 11, 1022. https://doi.org/10.3390/min11091022

Academic Editors: Carlos

Hoffmann Sampaio, Weslei

Monteiro Ambros and Bogdan

Grigore Cazacliu

Received: 27 August 2021

Accepted: 16 September 2021

Published: 19 September 2021

Publisher's Note: MDPI stays neutral with regard to jurisdictional claims in published maps and institutional affiliations.

Copyright: (C) 2021 by the authors Licensee MDPI, Basel, Switzerland. This article is an open access article distributed under the terms and conditions of the Creative Commons Attribution (CC BY) license (https:// creativecommons.org/licenses/by/ $4.0 /)$.

Abstract: Nickel smelting slag contains valuable metals including nickel and copper. Failure to recycle these metals wastes resources, and disposal of nickel slag in stockpiles results in environmental pollution. Nickel slag recycling is important, and metals can be recovered from slag by flotation. However, considering the complex forms in which valuable metals occur in nickel slag, high yields are difficult to achieve by direct flotation. In this study, nickel slag was modified by reduction and sulfurization to render it more amenable to metal recovery through flotation. The mechanism was assessed based on thermodynamics and elements' phase distributions. Thermodynamic analyses indicated the feasibility of nickel slag modification by reduction-sulfurization smelting. The results of chemical phase analysis show that the forms in which valuable metals occur in nickel slag can be modified by reduction-sulfurization, and the proportion of metals existing in sulfide and free metal states in nickel slag can be increased. Compared with the direct flotation of raw slag, the recovery of nickel and copper from top-blowing slag increased by $23.03 \%$ and $14.63 \%$, respectively. The recoveries of nickel and copper from settling slag increased by $49.68 \%$ and $43.65 \%$, respectively.

Keywords: nickel slag; reduction-sulfurization; melting modification; flotation

\section{Introduction}

Nickel is widely used in machinery, architecture, steelmaking, national defense, and other fields due to its advantageous physical and chemical properties [1]. It is essential for social development and is an indispensable non-ferrous metal. At present, the main methods of nickel extraction are pyrometallurgy and hydrometallurgy, with pyrometallurgy being the traditional method of nickel extraction [2-4]. However, a large amount of nickel smelting slag is produced by these processes. Approximately 6-16t of slag is discharged in the production of $1 \mathrm{t}$ of nickel $[5,6]$. In some studies, nickel in slag can be reduced by using $\mathrm{FeS}_{2}$ cleaning, settling, and reduction settling, and the results show that the effect of reduction settling is obvious [4,7,8]. However, there are still some nickel smelters (such as Jinchuan, China) that are limited by factors such as a high $\mathrm{MgO}$ content in the raw materials, a high slag viscosity, and process conditions, resulting in a high nickel content in nickel slag. At present, the primary nickel slag disposal method is stacking, which occupies a large amount of land and introduces serious pollution into water resources and soil near storage locations [9-11]. More importantly, the nickel slag produced by pyrometallurgy contains residual nickel and a broad array of other valuable metals [12-14]. These metals need to be recovered from nickel smelting slag for economic and environmental reasons [15-17].

Common methods used to extract valuable metals from waste slag include hydrometallurgy [18-21], pyrometallurgy [22-24], and flotation [25-27]. Considering production costs and secondary pollution, effective use of nickel slag in hydrometallurgy and pyrometallurgy is difficult to achieve [11,28-30]. Flotation is widely used due to its low cost, short process flow, and high production efficiency advantages [31-33]. However, in nickel slag, the nickel is chemically bound in the form of stable silicate, resulting in a very low recovery 
in grinding and flotation. In addition, considering the complex states and small particle sizes in which valuable metals occur in nickel slag (some nickel and copper exist in the form of oxides), complicating recovery via flotation, prior conversion to sulfides or elemental substances is expected to enhance yields [34,35]. Therefore, we need to modify the nickel slag to improve the recovery of valuable metals in the nickel slag by flotation. Through full understanding of the process mineralogy of nickel slag, this paper introduces reduction and sulfurization modification to achieve efficient recovery of valuable metals from nickel slag [36] and quantitatively assesses the effect of copper-nickel mineral modification in slag after reducing-sulfurizing smelting. Through theoretical thermodynamic and chemical phase analyses, the feasibility of nickel slag modification by reducing-sulfurizing smelting was evaluated, and the effects were verified by a flotation test.

\section{Materials and Methods}

\subsection{Materials}

The nickel slag used in this study was collected from a smelter in Gansu Province, China. The sample was divided into top blowing and settling slag. Top blowing slag and settling slag belong to the waste slag of nickel pyrometallurgical processes, and they come from different production systems. In oxygen-rich top blowing systems, the top blowing slag produced by the top blowing furnace contains more valuable metals, such as copper and nickel. The top blowing slag is then further treated and recovered by the settling furnace system. In the treatment process by the settling furnace system, settling slag is produced. The details are shown in Figure 1. The main chemical compositions of the samples are shown in Tables 1 and 2.

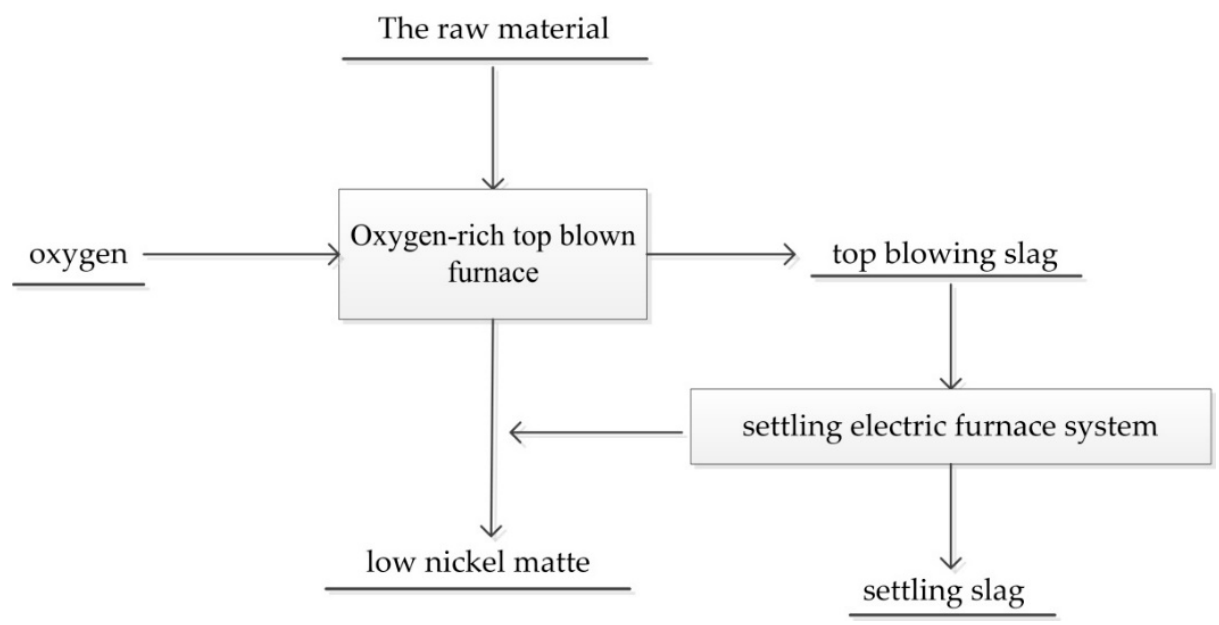

Figure 1. Detailed difference between top blowing slag and settling slag.

Table 1. Main chemical composition of top blowing slag ( $w \mathrm{t} \%)$.

\begin{tabular}{lcccccccc}
\hline Element & $\mathbf{N i}$ & $\mathrm{Cu}$ & $\mathrm{Fe}$ & $\mathrm{Co}$ & $\mathrm{Ca}$ & $\mathrm{MgO}$ & $\mathrm{SiO}_{2}$ & $\mathrm{~S}$ \\
\hline Content & 1.81 & 0.69 & 33.97 & 0.10 & 3.15 & 11.18 & 35.47 & 0.059 \\
\hline
\end{tabular}

Table 2. Main chemical composition of settling slag (wt $\%$ ).

\begin{tabular}{lcccccccc}
\hline Element & $\mathbf{N i}$ & $\mathbf{C u}$ & $\mathrm{Fe}$ & $\mathrm{Co}$ & $\mathrm{Ca}$ & $\mathbf{M g O}$ & $\mathrm{SiO}_{2}$ & $\mathrm{~S}$ \\
\hline Content & 0.88 & 0.31 & 34.26 & 0.088 & 3.28 & 12.50 & 37.87 & 0.40 \\
\hline
\end{tabular}

Tables 1 and 2 show that the nickel slag contains a considerable amount of valuable metals, with the content exceeding $30 \%(\mathrm{Fe}, \mathrm{Ni}$, and $\mathrm{Cu})$, among which iron is the main component, followed by nickel and copper. 
A chemical phase analysis of the samples was determined to measure the quantitative phase distribution characteristic of nickel and copper in the nickel slag [37]. The chemical phase analysis method is based on the solubility difference of various phases in a specific solvent $[9,37]$. Through the different solubilities of copper and nickel in various phases, different solutions were selected in which to dissolve the samples, and the content of nickel and copper in the prepared solution was determined using the atomic absorption method. The results (elements' phase distributions) of the samples are shown in Tables 3-6.

Table 3. Nickel's phase distributions in raw top blowing slag (wt $\%)$.

\begin{tabular}{cccccc}
\hline State & $\begin{array}{c}\text { Metallic } \\
\text { Nickel }\end{array}$ & $\begin{array}{c}\text { Nickel } \\
\text { Sulfide }\end{array}$ & $\begin{array}{c}\text { Nickel } \\
\text { Oxide }\end{array}$ & $\begin{array}{c}\text { Nickel } \\
\text { Silicate }\end{array}$ & Total Nickel \\
\hline Content & 0.535 & 0.64 & 0.589 & 0.016 & 1.78 \\
Occupancy & 30.05 & 35.96 & 33.09 & 0.90 & 100 \\
\hline
\end{tabular}

Table 4. Copper's phase distributions in raw top blowing slag (wt $\%)$.

\begin{tabular}{cccccc}
\hline State & $\begin{array}{c}\text { Metallic } \\
\text { Copper }\end{array}$ & $\begin{array}{c}\text { Copper } \\
\text { Sulfide }\end{array}$ & $\begin{array}{c}\text { Copper } \\
\text { Oxide }\end{array}$ & $\begin{array}{c}\text { Other } \\
\text { Copper }\end{array}$ & Total Copper \\
\hline Content & 0.15 & 0.38 & 0.108 & 0.032 & 0.67 \\
Occupancy & 22.39 & 56.71 & 16.12 & 4.78 & 100 \\
\hline
\end{tabular}

Table 5. Nickel's phase distributions in raw settling slag (wt $\%)$.

\begin{tabular}{cccccc}
\hline State & $\begin{array}{c}\text { Metallic } \\
\text { Nickel }\end{array}$ & $\begin{array}{c}\text { Nickel } \\
\text { Sulfide }\end{array}$ & $\begin{array}{c}\text { Nickel } \\
\text { Oxide }\end{array}$ & $\begin{array}{c}\text { Nickel } \\
\text { Silicate }\end{array}$ & Total Nickel \\
\hline Content & 0.032 & 0.586 & 0.172 & 0.09 & 0.88 \\
Occupancy & 3.64 & 66.59 & 19.55 & 10.22 & 100 \\
\hline
\end{tabular}

Table 6. Copper's phase distributions in raw settling slag (wt\%).

\begin{tabular}{cccccc}
\hline State & $\begin{array}{c}\text { Metallic } \\
\text { Copper }\end{array}$ & $\begin{array}{c}\text { Copper } \\
\text { Sulfide }\end{array}$ & $\begin{array}{c}\text { Copper } \\
\text { Oxide }\end{array}$ & $\begin{array}{c}\text { Other } \\
\text { Copper }\end{array}$ & Total Copper \\
\hline Content & 0.07 & 0.169 & 0.024 & 0.037 & 0.30 \\
Occupancy & 23.33 & 56.33 & 8.00 & 12.34 & 100 \\
\hline
\end{tabular}

Other copper consists of mainly copper in silicate minerals or encapsulated in silicate minerals of fine copper. It can be seen from Tables 3-6 that more copper and nickel in the nickel slag are in an oxidation state. By reduction-sulfurization, this part of the oxidation state of valuable metals can be converted into a sulfide state or a metal state to improve the recovery of valuable metals.

Carbon was used as a reducing agent in the experiments. The type of carbon is anthracite, and its main component is fixed carbon. The analysis results of its component are shown in Table 7.

Table 7. Results of carbon composition analysis (wt $\%$ ).

\begin{tabular}{cccc}
\hline Composition & Fixed Carbon & Ash & Volatile \\
\hline Content & 69.11 & 13.49 & 17.4 \\
\hline
\end{tabular}

\subsection{Experimental Methods}

The experimental process is composed of two steps (Figure 2), namely, the reducingsulfurizing smelting of the raw slag and the flotation of the modified slag. In the first step, the raw slag was crushed into pieces with a size of less than $0.074 \mathrm{~mm}$. Some raw 
slag samples were taken for analysis and detection, and the remaining slag was mixed with additives for reduction-sulfurization smelting. In the second step, the modified slag obtained after reduction smelting was crushed to less than $0.15 \mathrm{~mm}$. A part of modefied slag was taken for analysis and detection, the remaining slag was used for flotation test.

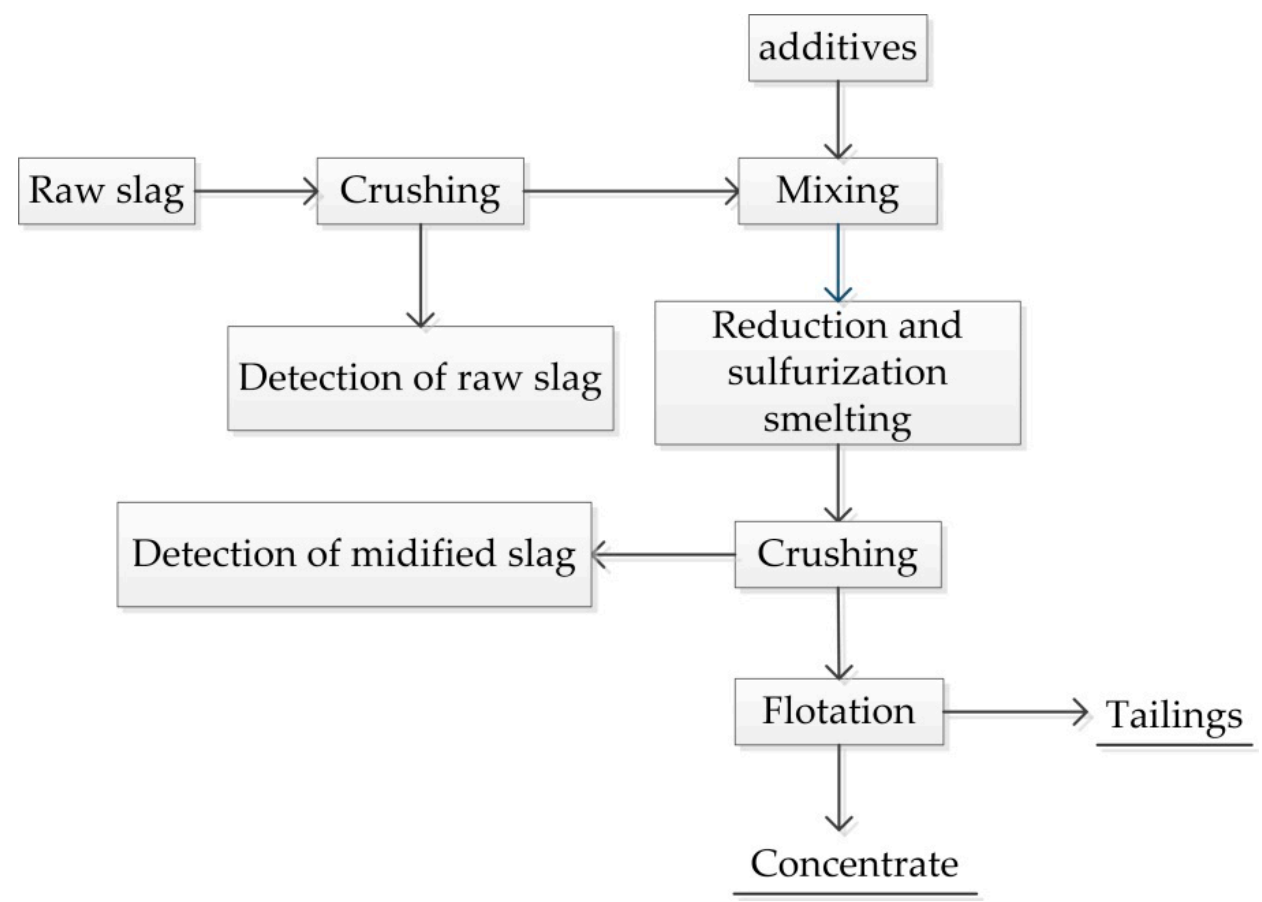

Figure 2. Flowchart of reducing-sulfurizing smelting and flotation test of nickel slag.

\subsubsection{Reduction-Sulfurization Smelting}

As shown in Figure 3, reduction-sulfurization smelting consists of the following steps. The nickel slag $(200 \mathrm{~g})$ with a particle size of less than $0.074 \mathrm{~mm}$ was evenly mixed with a certain amount of pyrite (3-15\%) and then poured into a $300 \mathrm{~mL}$ corundum crucible (without lid) in which a certain amount of carbon (0-8\%) was spread on the surface or mixed. These percentages represent the ratio of the mass of the additive to the mass of the raw slag. The crucible was placed in a redox reactor furnace in air atmosphere (no protective atmosphere was added, such as $\mathrm{N}_{2}$ ) (Figure 4), and the temperature was raised to $1400{ }^{\circ} \mathrm{C}$ at a rate of $8{ }^{\circ} \mathrm{C} / \mathrm{min}$. The temperature was maintained for $90 \mathrm{~min}$ to allow for enough time to pass for the furnace and slag to become even and stable. The temperature of the redox reactor furnace was slowly cooled to $950^{\circ} \mathrm{C}$ at a rate of $2{ }^{\circ} \mathrm{C} / \mathrm{min}$ [38]. The redox reactor furnace was opened, and the corundum crucible was naturally cooled to room temperature. The roasted nickel slag was separated from the crucible by manual crushing. The corundum crucible we used in the test contained more than $99 \% \mathrm{Al}_{2} \mathrm{O}_{3}$ and its melting point was more than $2000^{\circ} \mathrm{C}$, so the alumina was not dissolved in the slag. We then crushed the slag to less than $0.15 \mathrm{~mm}$ using a vibration mill for subsequent experiments.

\subsubsection{Flotation}

The roasted slag $(150 \mathrm{~g})$ was ground to less than $0.045 \mathrm{~mm}(90 \%)$. After grinding, a flotation experiment was conducted in a $0.5 \mathrm{~L}$ RK/FD-60 cell and then the flotation operation was carried out according to the procedure shown in Figure 5. During flotation recovery, the main shaft speed, scraper speed, and air capacity of flotation machine were $2150 \mathrm{rpm}, 1950 \mathrm{rpm}$, and $4 \mathrm{dm}^{3} / \mathrm{min}$, respectively. The results of the flotation experiments were used to compare the recovery effect of valuable metals from nickel slag. 


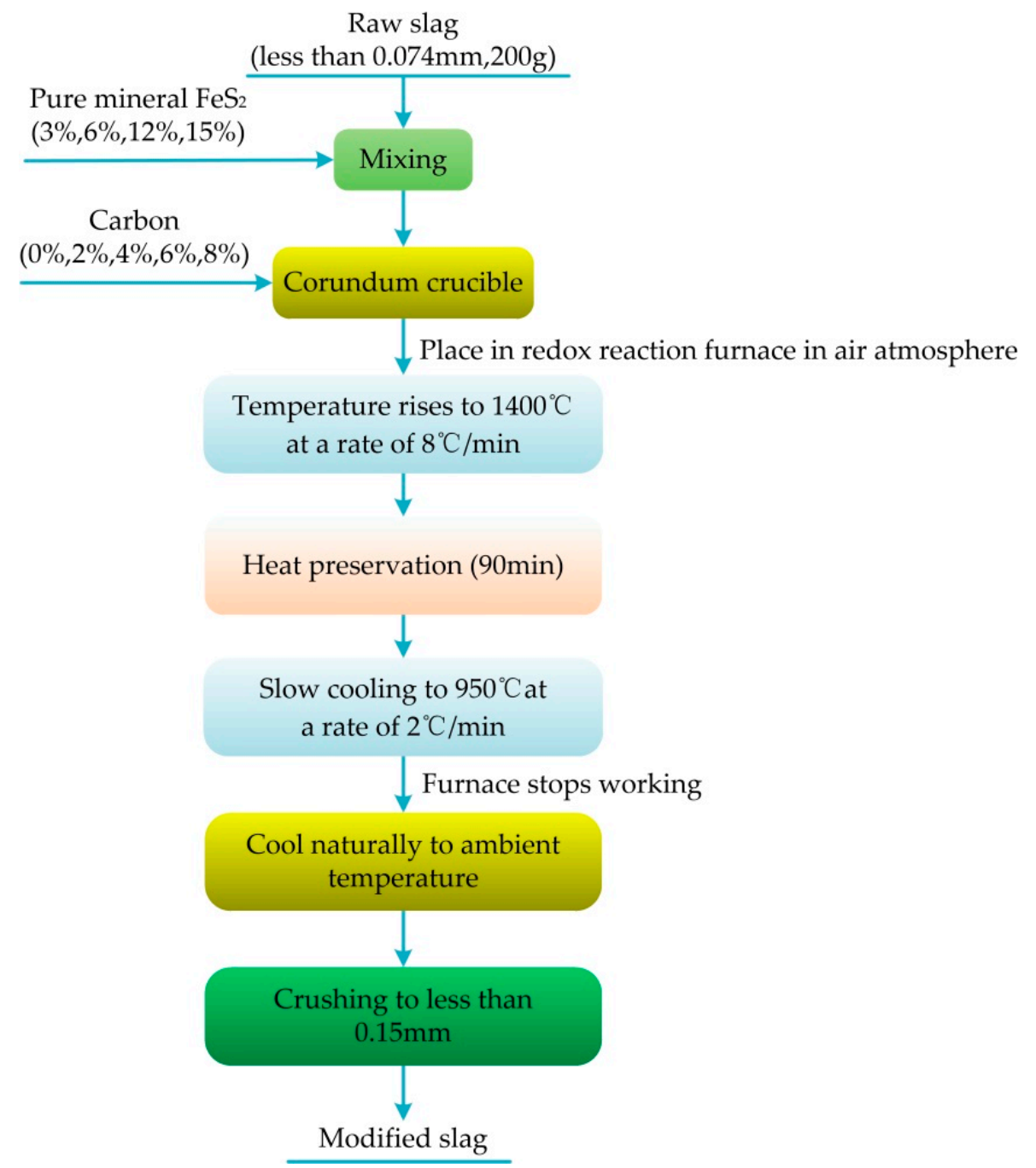

Figure 3. Flowchart of a reduction-sulfurization smelting experiment of nickel slag.

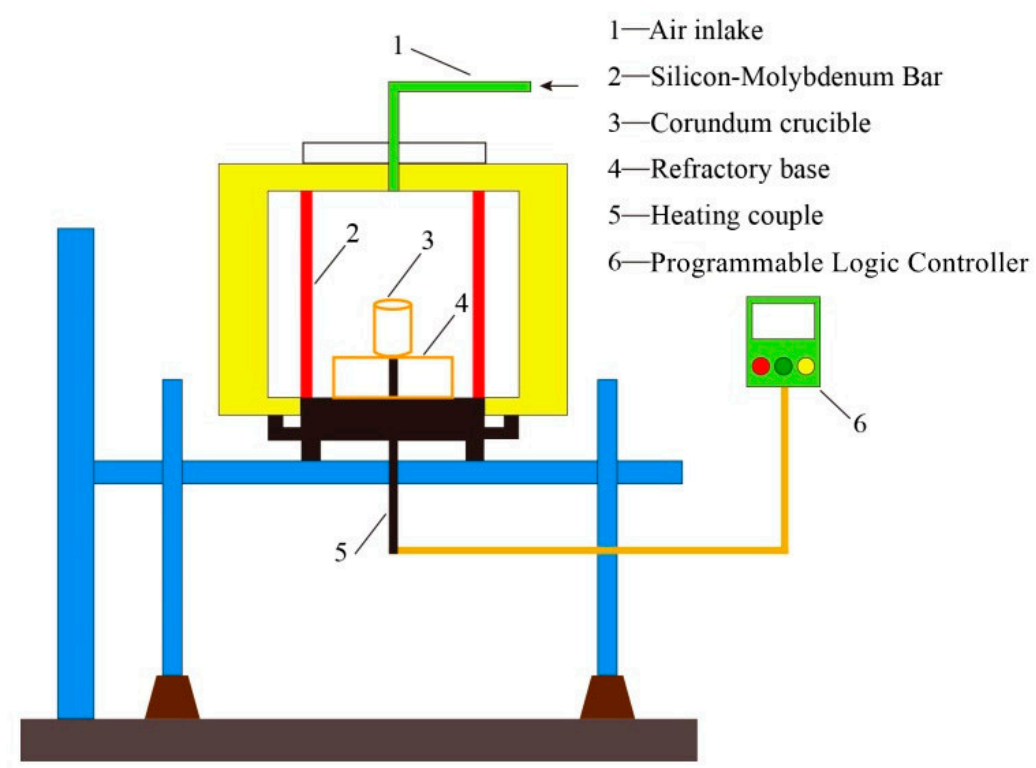

Figure 4. Schematic of the redox reaction furnace. 


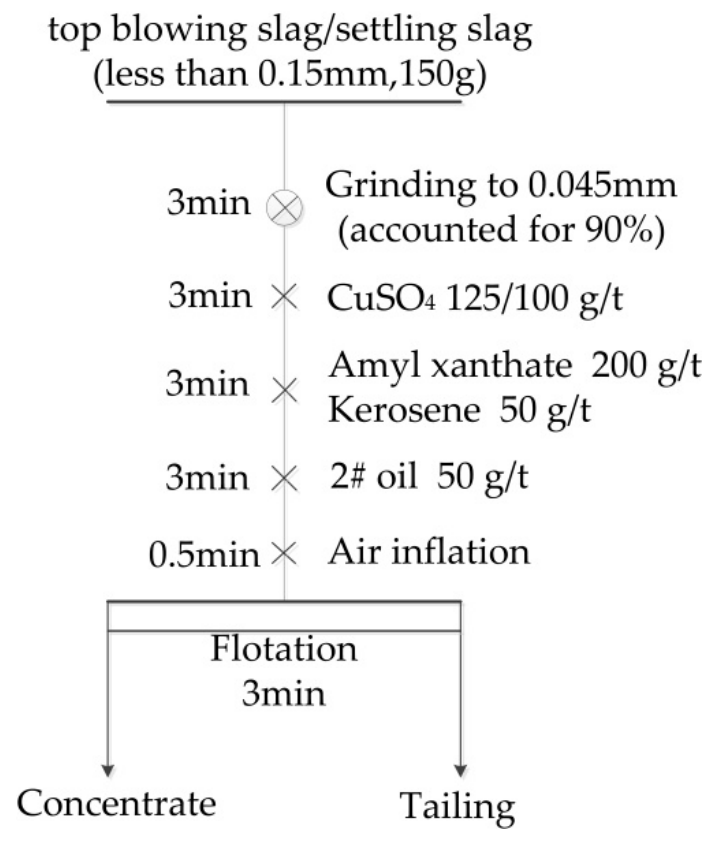

Figure 5. Flotation flowchart of nickel slag $(\otimes$ : Grinding; $\times$ : Dosing point).

The flotation index of modified slag was used to evaluate the recovery effect of valuable metals from nickel slag. The higher the grade and recovery of the flotation concentrate, the better the result. The grade of flotation products can be obtained by chemical analysis, and the recovery can be calculated using Equation (1) as follows:

$$
\varepsilon=\frac{m \cdot \beta}{m_{0} \cdot \alpha} \times 100 \%
$$

where $\varepsilon$ is the nickel recovery of flotation products (\%), $m$ is the mass of flotation products $(\mathrm{g}), m_{0}$ is the feed mass of modified sla1g for flotation $(\mathrm{g}), \beta$ is the nickel (copper) grade of flotation products (\%), and $\alpha$ is the nickel (copper) grade of the modified slag for flotation $(\%)$.

\subsubsection{Analytical Testing}

The composition of the nickel slag was determined by chemical analysis on the basis of the national standards (GB/T 223.7-2002, Standards Press of China, Beijing, China and GB/T 15249.3-2009, Standards Press of China, Beijing, China). The chemical composition of carbon was determined by GB/T212-2008 and GB/T219-2008. The Gibbs free energy of the main reactions in the process of the melting modification of nickel slag was calculated using the thermodynamic calculation software Factsage 7.1 (GTT, Washington, VA, USA).

\section{Results and Discussion}

\subsection{Thermodynamic Analysis}

Based on the process mineralogy analysis of nickel slag, some metals exist in the oxidation state in the raw slag. Therefore, on the basis of fully understanding the process mineralogy of nickel slag, pyrite and carbon were added to the nickel slag for reducingsulfurizing smelting in order to reduce the valuable metals in the oxidation state of nickel slag to the metal state or to sulfurize them into the sulfide state. First, the feasibility was analyzed using thermodynamic calculation. The possible reactions in the system are as follows:

$$
\begin{gathered}
\mathrm{Fe}_{3} \mathrm{O}_{4}+\mathrm{C}=3 \mathrm{FeO}+\mathrm{CO} \\
\mathrm{FeO}+\mathrm{C}=\mathrm{Fe}+\mathrm{CO}
\end{gathered}
$$




$$
\begin{gathered}
\mathrm{NiO}+\mathrm{Fe}=\mathrm{Ni}+\mathrm{FeO} \\
\mathrm{Cu}_{2} \mathrm{O}+\mathrm{Fe}=2 \mathrm{Cu}+\mathrm{FeO} \\
\mathrm{NiO}+\mathrm{C}=\mathrm{Ni}+\mathrm{CO} \\
\mathrm{Cu}{ }_{2} \mathrm{O}+\mathrm{C}=2 \mathrm{Cu}+\mathrm{CO} \\
\mathrm{FeO}+\mathrm{CO}=\mathrm{Fe}+\mathrm{CO}_{2} \\
\mathrm{NiO}+\mathrm{CO}=\mathrm{Ni}+\mathrm{CO}_{2} \\
\mathrm{Cu}_{2} \mathrm{O}+\mathrm{CO}=2 \mathrm{Cu}+\mathrm{CO}_{2} \\
\mathrm{C}+\mathrm{CO}_{2}=2 \mathrm{CO} \\
\mathrm{FeS}=\mathrm{FeS}+1 / 2 \mathrm{~S}_{2} \\
\mathrm{Cu}_{2} \mathrm{O}+1 / 2 \mathrm{Fe}_{2} \mathrm{O}_{3}+1 / 2 \mathrm{FeS}=3 / 2 \mathrm{FeO}+1 / 2 \mathrm{SO}_{2}+2 \mathrm{Cu} \\
\mathrm{Cu}_{2} \mathrm{O}+\mathrm{FeS}=\mathrm{FeO}+\mathrm{Cu} \mathrm{Cu}_{2} \\
\mathrm{NiO}+1 / 2 \mathrm{Fe}_{2} \mathrm{O}_{3}+1 / 2 \mathrm{FeS}=3 / 2 \mathrm{FeO}+1 / 2 \mathrm{SO}_{2}+\mathrm{Ni} \\
\mathrm{NiO}+\mathrm{FeS}=\mathrm{FeO}+\mathrm{NiS}
\end{gathered}
$$

The standard Gibbs free energy of the above reactions at $800-1400{ }^{\circ} \mathrm{C}$ was calculated, and the results are shown in Figure 6.
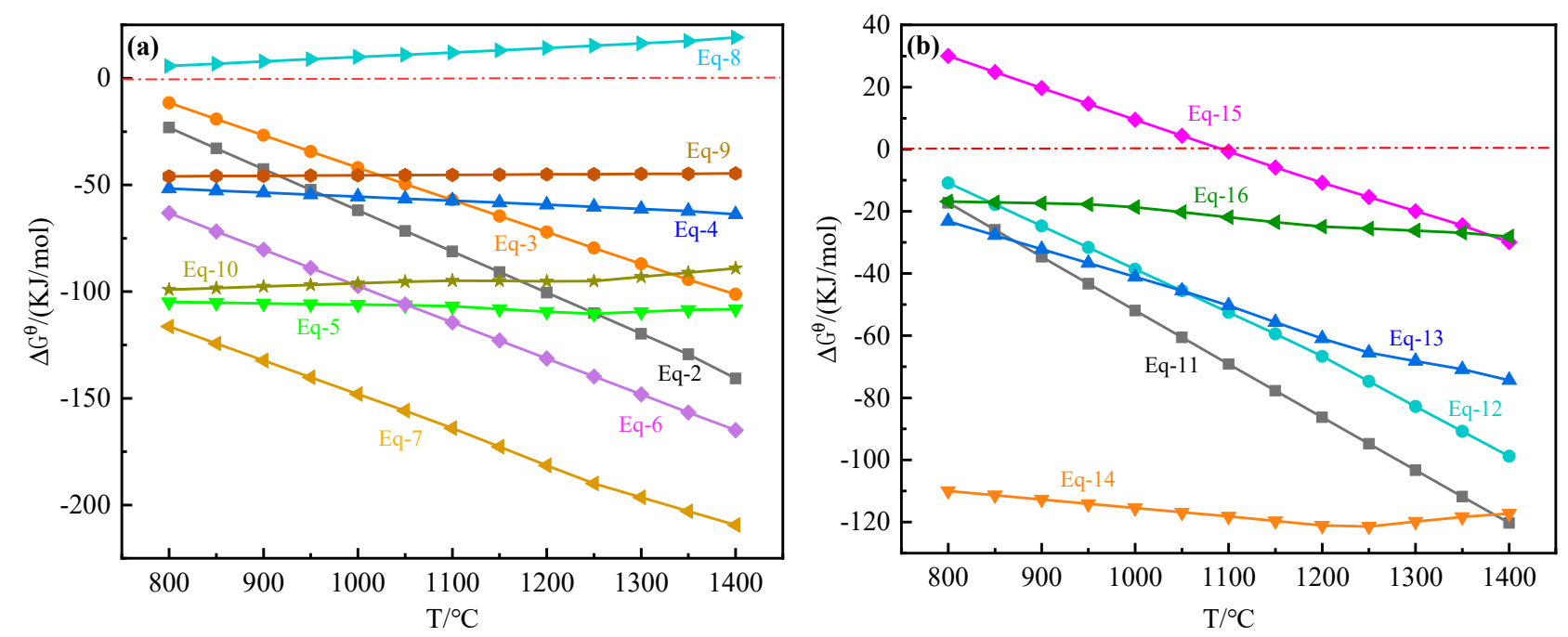

Figure 6. Gibbs free energy of a reduction-sulfurization reaction as a function of temperature. (a): Reactions (2)-(10); (b): Reactions (11)-(16).

As shown in Figure 6, within the temperature range of $800-1400{ }^{\circ} \mathrm{C}$, except for Equation (8), the Gibbs free energy of all reactions was less than zero, indicating that the above reactions may occur spontaneously under the standard state. According to Equations (2), (3), (6) and (7), the Gibbs free energy of Reaction (7) is lower than that of Reactions (2), (3) and (6) at the same temperature. This means Reaction (7) is more likely to occur, suggesting that copper is more likely to be reduced. According to Equations (14) and (16), the Gibbs free energy of Reaction (14) is lower than that of Reaction (16) at the same temperature. This means that Reaction (14) is more likely to occur, i.e., that copper is more likely to be sulfurized. 


\subsection{Flotation Experiment}

\subsubsection{The Influence of Carbon (Mixing)}

A fixed sulfide agent $\mathrm{FeS}_{2}$ and a nickel slag mass percentage of $15 \%$ were mixed with different amounts of carbon. According to the test method, the grade and recovery of nickel and copper in the concentrate recovered by flotation were investigated, and the results are shown in Figures 7 and 8.
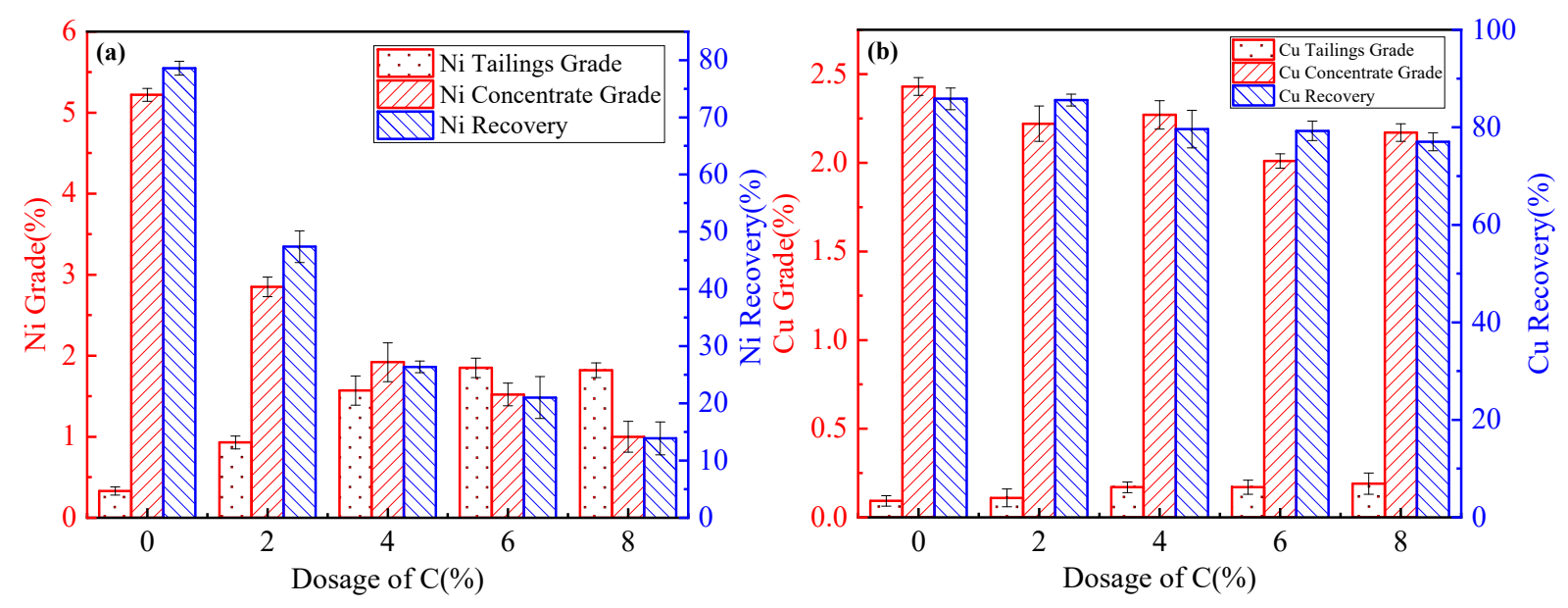

Figure 7. Influence of mixing carbon on the recovery of valuable metals in top blowing slag. (a) Influence of nickel; (b) Influence of copper. (Modifying at $1400{ }^{\circ} \mathrm{C}$ for $90 \mathrm{~min}$ and cooling at $2{ }^{\circ} \mathrm{C} / \mathrm{min}$ from 1400 to $950{ }^{\circ} \mathrm{C}$ ).

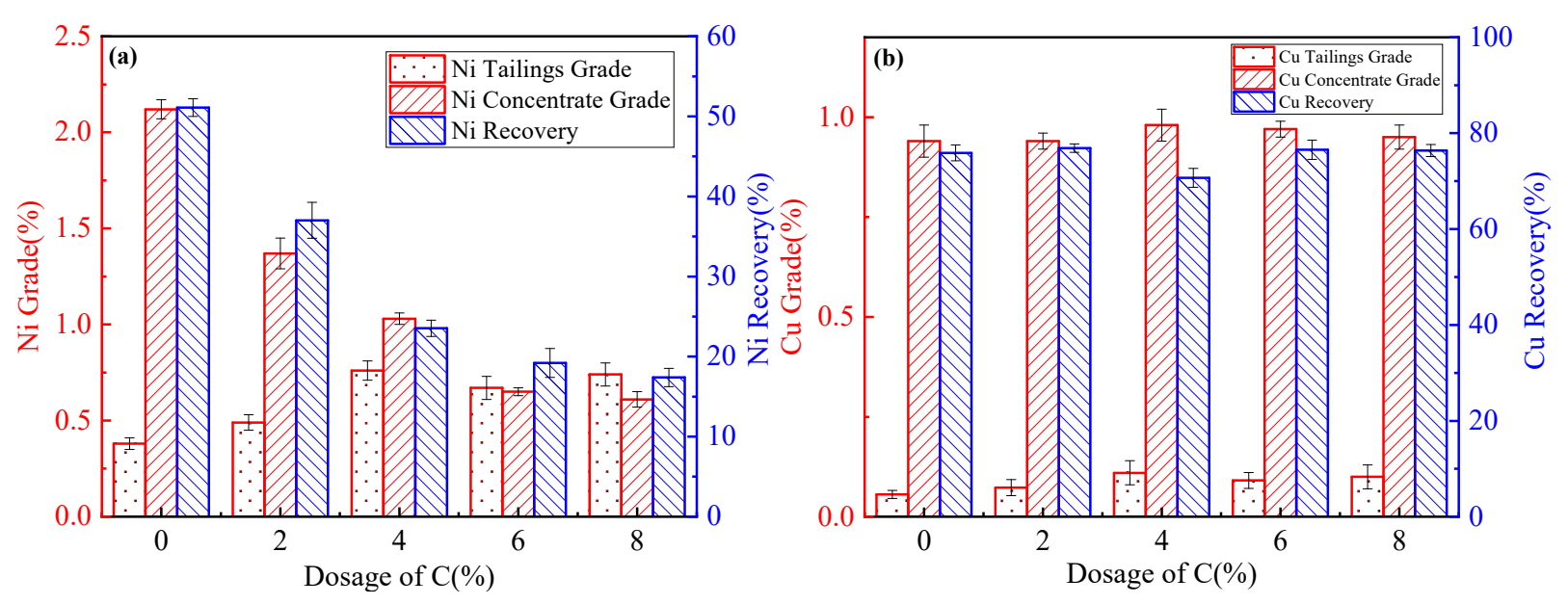

Figure 8. Influence of mixing carbon on the recovery of valuable metals in settling slag. (a) Influence of nickel; (b) Influence of copper. (Modifying at $1400{ }^{\circ} \mathrm{C}$ for $90 \mathrm{~min}$ and cooling at $2{ }^{\circ} \mathrm{C} / \mathrm{min}$ from 1400 to $950{ }^{\circ} \mathrm{C}$ ).

As shown in Figures 7 and 8, with the increase in the dosage of carbon, the grade and recovery of nickel in the concentrate decreases rapidly. It affects the recovery of nickel and has little effect on copper.

The reason why the mixed addition of carbon is not good for the flotation recovery of nickel from nickel slag is that the carbon can reduce the iron olivine in the slag to elemental iron [23] $\left(\mathrm{Fe}_{3} \mathrm{O}_{4}+\mathrm{C}=3 \mathrm{FeO}+\mathrm{CO}, \mathrm{FeO}+\mathrm{C}=\mathrm{Fe}+\mathrm{CO}\right)$. Moreover, with the addition of carbon, a large amount of nickel in the slag will be reduced $(\mathrm{NiO}+\mathrm{C}=\mathrm{Ni}+\mathrm{CO})$. Due to the siderophile properties of nickel [39,40], nickel-iron alloys are formed [41]. It cannot be recovered by flotation, which affects the recovery of nickel. 


\subsubsection{The Influence of Carbon (Top Carbon)}

A fixed sulfide agent $\mathrm{FeS}_{2}$ and a nickel slag mass percentage of $15 \%$ were added to the surface with different amounts of carbon. According to the test method, the grade and recovery of nickel and copper in the concentrate recovered by flotation were investigated, and the results are shown in Figures 9 and 10.

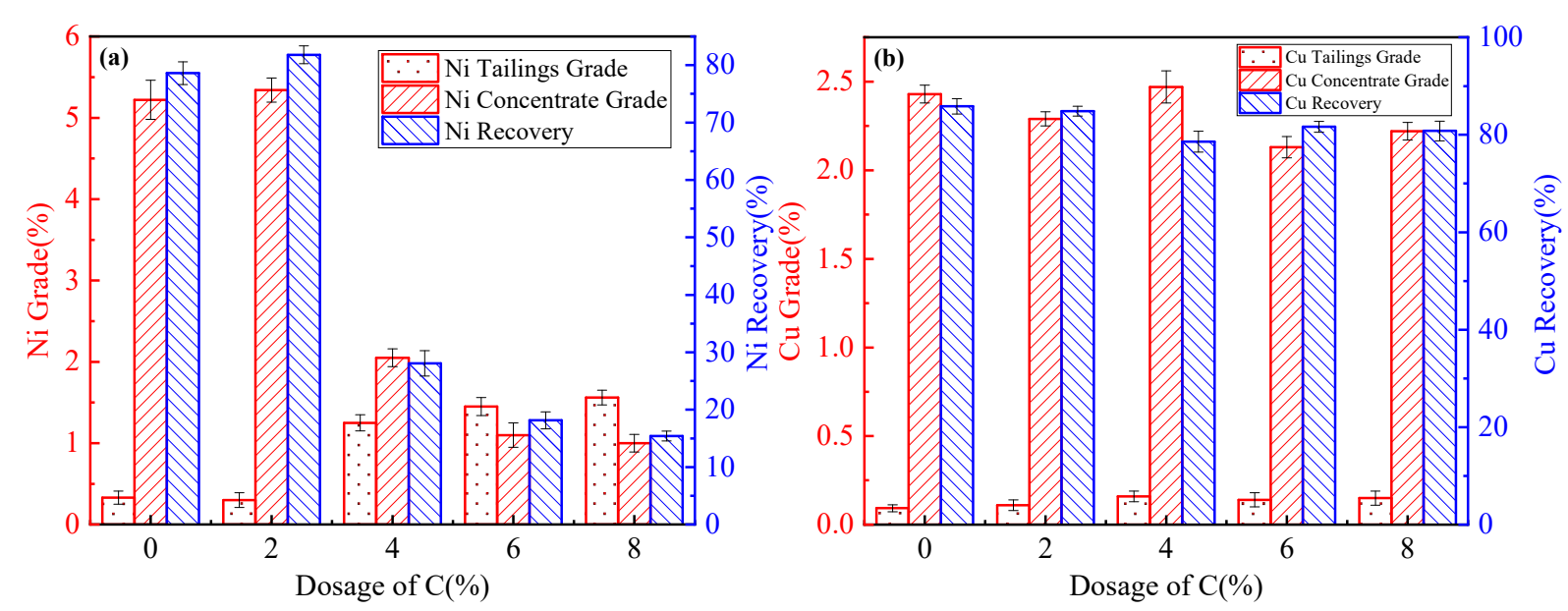

Figure 9. Influence of spreading carbon on the recovery of valuable metals in top blowing slag. (a) Influence of nickel; (b) Influence of copper. (Modifying at $1400{ }^{\circ} \mathrm{C}$ for $90 \mathrm{~min}$ and cooling at $2{ }^{\circ} \mathrm{C} / \mathrm{min}$ from 1400 to $950{ }^{\circ} \mathrm{C}$ ).
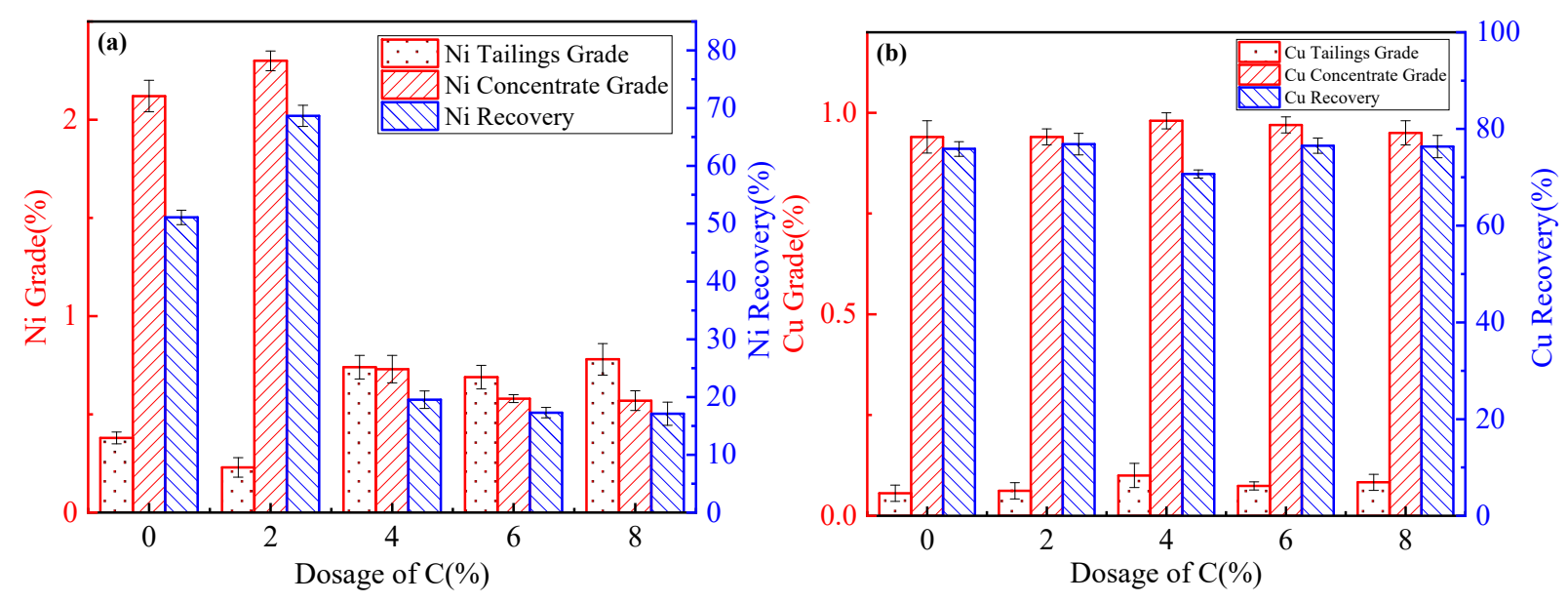

Figure 10. Influence of spreading carbon on the recovery of valuable metals in settling slag. (a) Influence of nickel; (b) Influence of copper. (Modifying at $1400{ }^{\circ} \mathrm{C}$ for $90 \mathrm{~min}$ and cooling at $2{ }^{\circ} \mathrm{C} / \mathrm{min}$ from 1400 to $950{ }^{\circ} \mathrm{C}$ ).

As shown in Figures 9 and 10, a small amount of carbon added to the surface can improve the grade and recovery of nickel in the concentrate. When the carbon dosage is $2 \%$ (top carbon), the concentrate grade of nickel in top blowing slag can be increased by $0.12 \%$, the recovery of nickel can be increased by $3.19 \%$, the concentrate grade of nickel in settling slag can be increased by $0.18 \%$, and the recovery of nickel can be increased by $17.58 \%$ compared with no carbon addition. When the carbon dosage is $2 \%$ (mixing), compared with no carbon addition, the concentrate grade of nickel in a top blowing slag is reduced by $2.37 \%$, the recovery of nickel is reduced by $31.21 \%$, the concentrate grade of nickel in settling slag is reduced by $0.75 \%$, and the recovery of nickel is reduced by $14.09 \%$. Therefore, the effect of proper carbon spreading is better than that of carbon mixing.

When the amount of carbon spreading is less, the carbon spreading on the surface of the material can play a role in oxygen isolation. The pyrite can sulfurize the oxidized 
copper and nickel in the slag and can prevent the raw material from being oxidized twice when contacting oxygen. However, when the amount of carbon is increased, too much carbon reduces the nickel in the slag at high temperature. The elemental iron also removes a large amount of nickel from the precipitated alloy [23]. Therefore, for this experiment, it is appropriate to add $2 \%$ carbon for spreading.

\subsubsection{The Influence of $\mathrm{FeS}_{2}$}

Mixed with different amounts of $\mathrm{FeS}_{2}$, the fixed reducing agent carbon and nickel slag mass percentage of $2 \%$ were spread on the material surface. According to the test method, the grade and recovery of nickel and copper in the concentrate recovered by flotation were investigated (the $\mathrm{FeS}_{2}$ dosage of 0 means direct flotation of raw slag), and the results are shown in Figures 11 and 12.
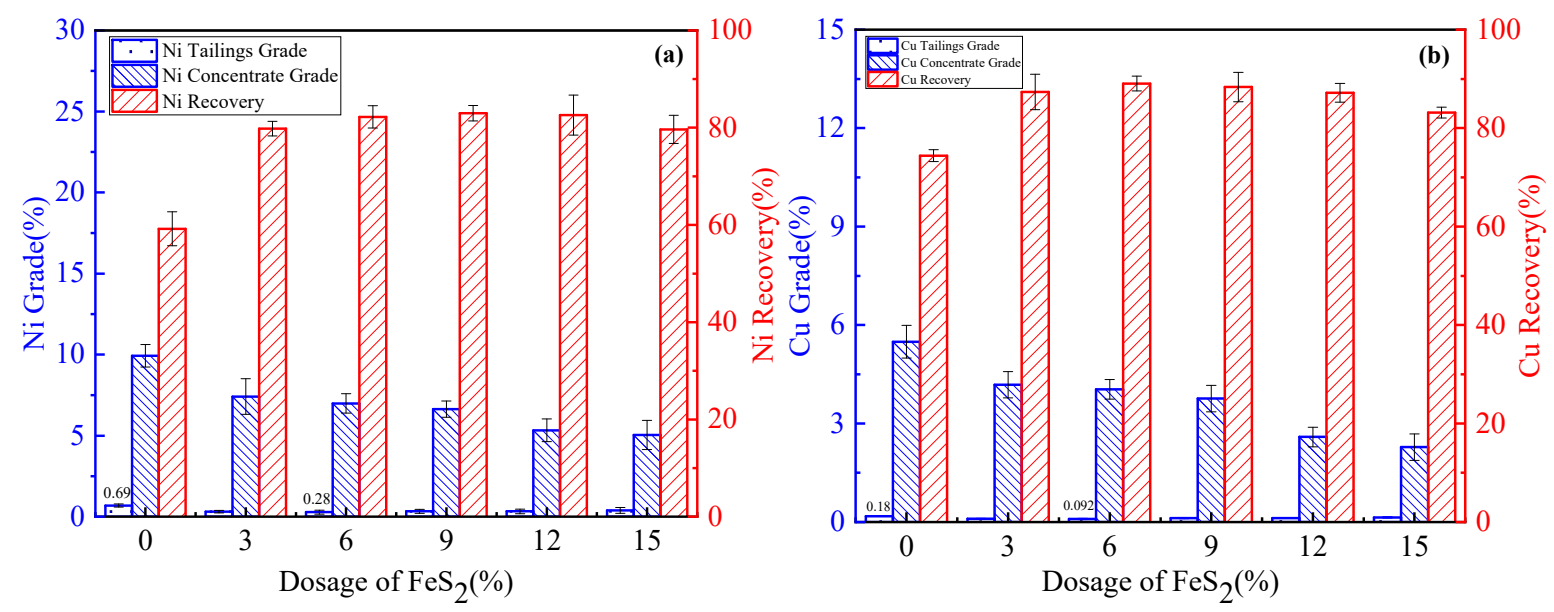

Figure 11. Influence of $\mathrm{FeS}_{2}$ on the recovery of valuable metals in top blowing slag. (a) Influence of nickel; (b) Influence of copper. (Modifying at $1400{ }^{\circ} \mathrm{C}$ for $90 \mathrm{~min}$ and cooling at $2{ }^{\circ} \mathrm{C} / \mathrm{min}$ from 1400 to $950{ }^{\circ} \mathrm{C}$ ).
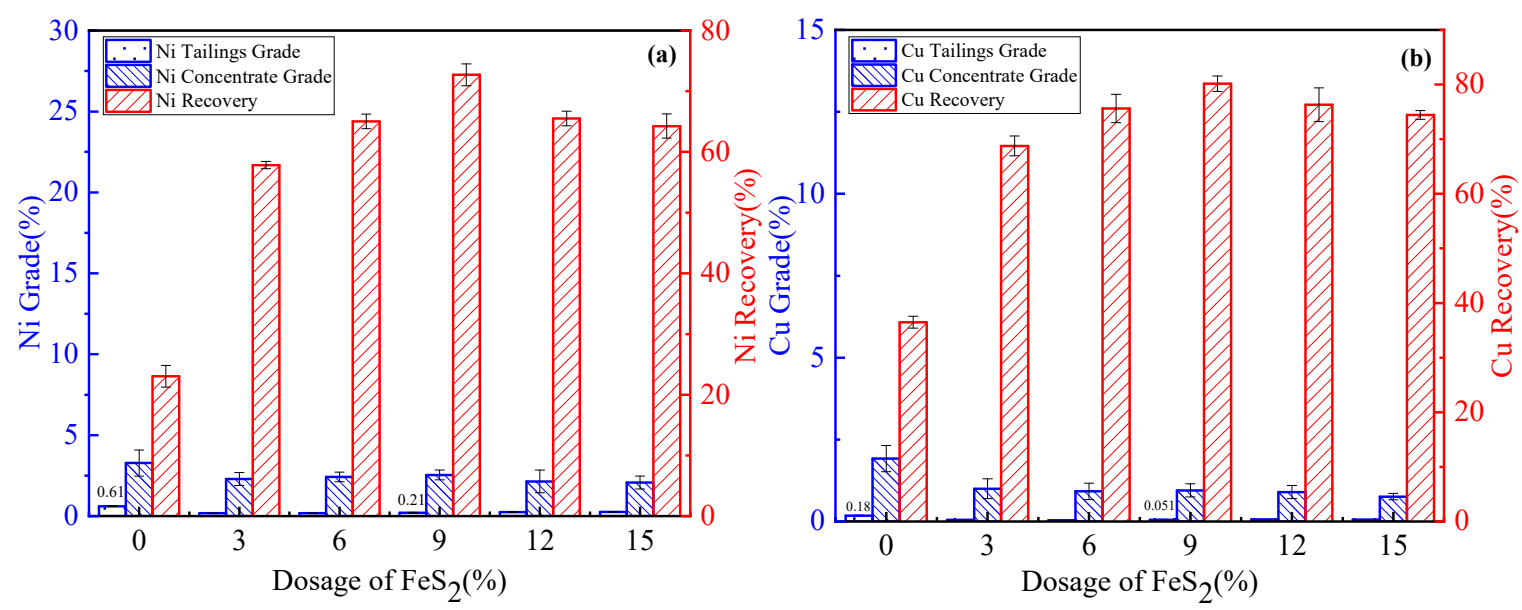

Figure 12. Influence of $\mathrm{FeS}_{2}$ on the recovery of valuable metals in settling slag. (a) Influence of nickel; (b) Influence of copper. (Modifying at $1400{ }^{\circ} \mathrm{C}$ for $90 \mathrm{~min}$ and cooling at $2{ }^{\circ} \mathrm{C} / \mathrm{min}$ from 1400 to $950{ }^{\circ} \mathrm{C}$ ).

According to the results, the addition of pyrite remarkably improved the flotation recovery of valuable metals from nickel slag. For the top blowing slag, with the increase in pyrite dosage from $3 \%$ to $15 \%$, the recovery of nickel and copper in flotation concentrate first increased and then decreased. When the dosage of pyrite was $6 \%$, the recovery of nickel and copper reached the best value. The grade and recovery of nickel concentrate were $6.99 \%$ and $82.22 \%$, respectively. In comparison with the direct flotation of raw slag, 
the recovery can be increased by $23.03 \%$. The grade and recovery of copper concentrate were $4.04 \%$ and $89.05 \%$, respectively. In comparison with the direct flotation of raw slag, the recovery can be increased by $14.63 \%$. At the same time, the grade of nickel in tailings can be decreased from $0.69 \%$ to $0.28 \%$, and the grade of copper in tailings can be decreased from $0.18 \%$ to $0.092 \%$.

For settling slag, with the increase in pyrite dosage from 3\% to $15 \%$, the recovery of nickel and copper in flotation concentrate increased first and then decreased. When the dosage of pyrite was $9 \%$, the recovery of nickel and copper reached the best value. The grade and recovery of nickel concentrate were $2.54 \%$ and $72.51 \%$. In comparison with the direct flotation of raw slag, the recovery can be increased by $49.68 \%$. The grade and recovery of copper concentrate were $0.95 \%$ and $80.14 \%$, respectively, and the recovery of copper can be increased by $43.65 \%$ compared with the direct flotation of raw slag. At the same time, the grade of nickel in tailings can be decreased from $0.61 \%$ to $0.21 \%$, and the grade of copper in tailings can be decreased from $0.18 \%$ to $0.051 \%$.

When the valuable metals in the nickel slag were reduced or sulfurized, the state of the valuable metals changed to the metal or sulfurized state, which is easy to float. The smelting products under the optimal reduction smelting conditions were selected for chemical phase analysis, and the results are shown in Tables 8-11.

Table 8. Nickel's phase distributions in modified top blowing slag (wt\%).

\begin{tabular}{cccccc}
\hline State & $\begin{array}{c}\text { Metallic } \\
\text { Nickel }\end{array}$ & $\begin{array}{c}\text { Nickel } \\
\text { Sulfide }\end{array}$ & $\begin{array}{c}\text { Nickel } \\
\text { Oxide }\end{array}$ & $\begin{array}{c}\text { Nickel } \\
\text { Silicate }\end{array}$ & Total Nickel \\
\hline Content & 0.71 & 0.87 & 0.0053 & 0.013 & 1.60 \\
Occupancy & 44.38 & 54.38 & 0.33 & 0.81 & 100 \\
\hline
\end{tabular}

Table 9. Copper's phase distributions in modified top blowing slag (wt $\%)$.

\begin{tabular}{cccccc}
\hline State & $\begin{array}{c}\text { Metallic } \\
\text { Copper }\end{array}$ & $\begin{array}{c}\text { Copper } \\
\text { Sulfide }\end{array}$ & $\begin{array}{c}\text { Copper } \\
\text { Oxide }\end{array}$ & $\begin{array}{c}\text { Other } \\
\text { Copper }\end{array}$ & Total Copper \\
\hline Content & 0.002 & 0.63 & 0.008 & 0.01 & 0.65 \\
Occupancy & 0.31 & 96.92 & 1.23 & 1.54 & 100 \\
\hline
\end{tabular}

Table 10. Nickel's phase distributions in modified settling slag (wt $\%)$.

\begin{tabular}{cccccc}
\hline State & $\begin{array}{c}\text { Metallic } \\
\text { Nickel }\end{array}$ & $\begin{array}{c}\text { Nickel } \\
\text { Sulfide }\end{array}$ & $\begin{array}{c}\text { Nickel } \\
\text { Oxide }\end{array}$ & $\begin{array}{c}\text { Nickel } \\
\text { Silicate }\end{array}$ & Total Nickel \\
\hline Content & 0.41 & 0.23 & 0.0044 & 0.013 & 0.66 \\
Occupancy & 62.12 & 34.85 & 0.67 & 1.97 & 100 \\
\hline
\end{tabular}

Table 11. Copper's phase distributions in modified settling slag ( $\mathrm{wt} \%)$.

\begin{tabular}{cccccc}
\hline State & $\begin{array}{c}\text { Metallic } \\
\text { Copper }\end{array}$ & $\begin{array}{c}\text { Copper } \\
\text { Sulfide }\end{array}$ & $\begin{array}{c}\text { Copper } \\
\text { Oxide }\end{array}$ & $\begin{array}{c}\text { Other } \\
\text { Copper }\end{array}$ & Total copper \\
\hline Content & 0.001 & 0.2 & 0.002 & 0.017 & 0.22 \\
Occupancy & 0.45 & 90.91 & 0.91 & 7.73 & 100 \\
\hline
\end{tabular}

According to the results, nickel mainly exists in the sulfide and metal phases in modified slag. The proportion of nickel sulfide and metal nickel in the modified top blowing slag reached $98.76 \%$, while those in the modified settling slag reached $96.97 \%$. Copper mainly exists in the sulfide phase; the proportion of copper sulfide in the modified top blowing slag was $96.92 \%$, and that in the modified settling slag was $90.91 \%$. In comparison with the raw slag, the proportion of sulfide and metal phases greatly increased, 
indicating that flotation after modification can improve the recovery of valuable metals in nickel slag.

The reason why an appropriate pyrite dosage can improve copper and nickel flotation recovery is that pyrite changes the state of copper and nickel in slag, as shown in Tables 8-11. It can be seen that copper mainly exists in slag in the form of copper sulfide and that nickel mainly exists in the form of nickel sulfide and metallic nickel. This phenomenon indicates that copper oxide and nickel oxide may be converted to copper matte or nickel matte; similar results have been reported in [37]. Copper and nickel in these states can be easily recovered by flotation $[34,35]$.

Excess pyrite affects the grade of nickel and copper in the flotation concentrate [42]. Therefore, when the amount of pyrite increases, the recovery of nickel and copper decreases. When the amount of pyrite is appropriate, the oxidation state metals in the nickel slag react and the recovery of the valuable metals in the flotation concentrate reaches the highest value.

\section{Conclusions}

In this paper, a series of laboratory tests were conducted to explore the role of pyrite in the modification of nickel smelting slag and its effect on valuable metals recovery by flotation. The following conclusions were drawn:

1. In this study, the main consideration was the recovery of nickel and copper. For top blowing slag, the nickel and copper contents are $1.81 \%$ and $0.69 \%$, respectively. In the chemical phase, the proportion of nickel sulfide and nickel metal is $66.02 \%$, and that of copper sulfide and copper metal is $79.1 \%$. For settling slag, the nickel and copper contents are $0.88 \%$ and $0.31 \%$, respectively. In the chemical phase, the proportion of nickel sulfide and nickel metal is $70.23 \%$, and that of copper sulfide and copper metal is $79.66 \%$. It is not easy to recover these metals using direct flotation.

2. The nickel slag was modified by reduction and sulfurization. The proportion of nickel sulfide and nickel metal in the modified top blowing slag increased by $32.74 \%$ and the proportion of copper sulfide and copper metal increased by $18.13 \%$ compared with the raw slag. The proportion of nickel sulfide and nickel metal in the modified settling slag increased by $26.74 \%$, and the proportion of copper sulfide and copper metal increased by $11.7 \%$ compared with the raw slag.

3. In comparison with the direct flotation recovery of the raw slag, the recovery of nickel and copper in the top blowing slag can be increased by $23.03 \%$ and $14.63 \%$, while those in the settling slag can be increased by $49.68 \%$ and $43.65 \%$ by flotation after modification.

4. In comparison with the direct flotation recovery of the raw slag, the grade of tailings of nickel and copper in the top blowing slag can be decreased by $0.41 \%$ and $0.088 \%$, while those in the settling slag can be decreased by $0.40 \%$ and $0.129 \%$ by flotation after modification.

Author Contributions: Data curation, R.L.; formal analysis, X.L, Q.Z. and J.L.; funding acquisition, W.S. and R.L.; project administration, W.S.; supervision, W.S.; validation, X.L., Q.Z. and J.L.; writingoriginal draft, X.L.; writing-review and editing, R.L. All authors have read and agreed to the published version of the manuscript.

Funding: This study was financially supported by the National Key Scientific Research Project (grant Nos. 2018YFC1900305, 2018YFC1901601, 2018YFC1901602, and 2018YFC1901605).

Data Availability Statement: Not applicable.

Acknowledgments: We would like to thank the Central South University for providing us with the experimental platform.

Conflicts of Interest: The authors declare no conflict of interest. 


\section{References}

1. Marenych, O.; Kostryzhev, A. Strengthening Mechanisms in Nickel-Copper Alloys: A Review. Metals 2020, 10, 1358. [CrossRef]

2. Patrick, J.; Prasetyo, A.B.; Munir, B.; Maksum, A.; Soedarsono, J.W. The effect of addition of sodium sulphate $\left(\mathrm{Na}_{2} \mathrm{SO}_{4}\right)$ to nickel slag pyrometallurgical process with temperature and additives ratio as variables. In Proceedings of the 3rd International Tropical Renewable Energy Conference Sustainable Development of Tropical Renewable Energy, Bali, Indonesia, 6-8 September 2018.

3. Yucel, O.; Turan, A.; Yildirim, H. Investigation of Pyrometallurgical Nickel Pig Iron (NPI) Production Process from Lateritic Nickel Ores. In Proceedings of the 3rd International Symposium on High-Temperature Metallurgical Processing; Wiley: Hoboken, NJ, USA, 2012; pp. 17-23.

4. Mäkinen, T.; Taskinen, P. State of the art in nickel smelting: Direct Outokumpu nickel technology. Miner. Process. Extr. Metall. 2013, 117, 86-94. [CrossRef]

5. Zhang, G.; Wang, N.; Chen, M.; Cheng, Y. Recycling Nickel Slag by Aluminum Dross: Iron-extraction and Secondary Slag Stabilization. ISIJ Int. 2020, 60, 602-609. [CrossRef]

6. Wu, Q.; Wu, Y.; Tong, W.; Ma, H. Utilization of nickel slag as raw material in the production of Portland cement for road construction. Constr. Build. Mater. 2018, 193, 426-434. [CrossRef]

7. Nyman, B.; Aaltonen, A.; Hultholm, S.-E.; Karpale, K. Application of new hydrometallurgical developments in the Outokumpu HIKO process. Hydrometallurgy 1992, 29, 461-478. [CrossRef]

8. Davenport, W.G.; King, M.; Schlesinger, M.; Biswas, A.K. Chapter 5-Flash Smelting-Outokumpu Process1. In Extractive Metallurgy of Copper, 4th ed.; Davenport, W.G., Ed.; Pergamon: Oxford, UK, 2002; pp. 73-90.

9. Guo, Z.; Pan, J.; Zhu, D.; Zhang, F. Green and efficient utilization of waste ferric-oxide desulfurizer to clean waste copper slag by the smelting reduction-sulfurizing process. J. Clean. Prod. 2018, 199, 891-899. [CrossRef]

10. Dimitrijevic, M.; Kostov, A.; Tasić, V.; Milošević, N. Influence of pyrometallurgical copper production on the environment. J. Hazard. Mater. 2009, 164, 892-899. [CrossRef]

11. Li, B.; Rong, T.; Du, X.; Shen, Y.; Shen, Y. Preparation of Fe3O4 particles with unique structures from nickel slag for enhancing microwave absorption properties. Ceram. Int. 2021, 47, 18848-18857. [CrossRef]

12. Avarmaa, K.; Taskinen, P.; Klemettinen, L.; O’Brien, H.; Lindberg, D. Ni-Fe-Co alloy-Magnesia-iron-silicate slag equilibria and the behavior of minor elements $\mathrm{Cu}$ and $\mathrm{P}$ in nickel slag cleaning. J. Mater. Res. Technol. 2021, 15, 719-730. [CrossRef]

13. Wang, Q.; Yu, C.; Yang, J.; Chong, L.; Xu, X.; Wu, Q. Influence of nickel slag powders on properties of magnesium potassium phosphate cement paste. Constr. Build. Mater. 2019, 205, 668-678. [CrossRef]

14. Gbor, P.; Ahmed, I.; Jia, C. Behaviour of Co and Ni during aqueous sulphur dioxide leaching of nickel smelter slag. Hydrometallurgy 2000, 57, 13-22. [CrossRef]

15. Gorai, B.; Jana, R. Premchand Characteristics and utilisation of copper slag-A review. Resour. Conserv. Recycl. 2003, 39, 299-313. [CrossRef]

16. Guo, Z.; Zhu, D.; Pan, J.; Zhang, F. Innovative methodology for comprehensive and harmless utilization of waste copper slag via selective reduction-magnetic separation process. J. Clean. Prod. 2018, 187, 910-922. [CrossRef]

17. Gupta, B.; Deep, A.; Tandon, S.N. Recovery of Chromium and Nickel from Industrial Waste. Ind. Eng. Chem. Res. 2002, 41, 2948-2952. [CrossRef]

18. Gao, F.; Huang, Z.; Li, H.; Li, X.; Wang, K.; Hamza, M.F.; Wei, Y.; Fujita, T. Recovery of magnesium from ferronickel slag to prepare hydrated magnesium sulfate by hydrometallurgy method. J. Clean. Prod. 2021, 303, 127049. [CrossRef]

19. Wang, H.-J.; Liu, Z.-Y.; Liu, Z.-H.; Li, Y.-H.; Li, S.-W.; Zhang, W.-H.; Li, Q.-H. Leaching of iron concentrate separated from kiln slag in zinc hydrometallurgy with hydrochloric acid and its mechanism. Trans. Nonferrous Met. Soc. China 2017, 27, 901-907. [CrossRef]

20. Pan, D.; Li, L.; Tian, X.; Wu, Y.; Cheng, N.; Yu, H. A review on lead slag generation, characteristics, and utilization. Resour. Conserv. Recycl. 2019, 146, 140-155. [CrossRef]

21. Huang, F.; Liao, Y.; Zhou, J.; Wang, Y.; Li, H. Selective recovery of valuable metals from nickel converter slag at elevated temperature with sulfuric acid solution. Sep. Purif. Technol. 2015, 156, 572-581. [CrossRef]

22. Barry, T.I.; Dinsdale, A.T.; Martin, S.M.; Taylor, J.R., II. 13-Pyrometallurgy of copper-nickel-iron sulphide ores: The calculation of the distribution of components between matte, slag, alloy and gas phases. In The SGTE Casebook, 2nd ed.; Hack, K., Ed.; Woodhead Publishing: Sawston, UK, 2008; pp. 188-199.

23. Guo, Z.; Wang, Y.; Li, S.; Pan, J.; Zhu, D.; Yang, C.; Pan, L.; Tian, H.; Wang, D. Reductive roasting mechanism of copper slag and nickel laterite for Fe-Ni-Cu alloy production. J. Mater. Res. Technol. 2020, 9, 7602-7614. [CrossRef]

24. Shen, H.; Liu, B.; Shi, Z.; Zhao, S.; Zhang, J.; Zhang, S. Reduction for heavy metals in pickling sludge with aluminum nitride in secondary aluminum dross by pyrometallurgy, followed by glass ceramics manufacture. J. Hazard. Mater. 2021, $418,126331$. [CrossRef]

25. Yang, T.; Wang, N.; Gu, H.; Guo, T. Froth flotation separation of carbon from barium slag: Recycling of carbon and minimize the slag. Waste Manag. 2021, 120, 108-113. [CrossRef]

26. Roy, S.; Datta, A.; Rehani, S. Flotation of copper sulphide from copper smelter slag using multiple collectors and their mixtures. Int. J. Miner. Process. 2015, 143, 43-49. [CrossRef]

27. Szépvölgyi, J.; Bertóti, I.; Varga, I.; Mohai, M.; Székely, T.; Párkányi, I. Studies on the flotation of a non-ferrous slag. Miner. Eng. 1988, 1, 127-136. [CrossRef] 
28. Khalid, M.K.; Hamuyuni, J.; Agarwal, V.; Pihlasalo, J.; Haapalainen, M.; Lundström, M. Sulfuric acid leaching for capturing value from copper rich converter slag. J. Clean. Prod. 2019, 215, 1005-1013. [CrossRef]

29. Loveday, B. The use of oxygen in high pressure acid leaching of nickel laterites. Miner. Eng. 2008, 21, 533-538. [CrossRef]

30. Nadirov, R.K. Recovery of Valuable Metals from Copper Smelter Slag by Sulfation Roasting. Trans. Indian Inst. Met. 2018, 72, 603-607. [CrossRef]

31. Sarrafi, A.; Rahmati, B.; Hassani, H.; Shirazi, H. Recovery of copper from reverberatory furnace slag by flotation. Miner. Eng. 2004, 17, 457-459. [CrossRef]

32. Fan, J.; Li, H.; Wei, L.; Li, C.; Sun, S. The Recovery of Copper from Smelting Slag by Flotation Process. In Applications of Process Engineering Principles in Materials Processing, Energy and Environmental Technologies; Wang, S., Free, M.L., Alam, S., Zhang, M., Taylor, P., Eds.; Springer: Cham, Switzerland, 2017; pp. 231-237.

33. Bruckard, W.; Somerville, M.; Hao, F. The recovery of copper, by flotation, from calcium-ferrite-based slags made in continuous pilot plant smelting trials. Miner. Eng. 2004, 17, 495-504. [CrossRef]

34. Liu, D.; Zhang, G.; Liu, J.; Pan, G.; Chen, Y.; Wang, M. Studies on the surface oxidation and its role in the flotation of mixed Cu-Ni sulfide ore. Powder Technol. 2021, 381, 576-584. [CrossRef]

35. Zhao, K.; Yan, W.; Wang, X.; Wang, Z.; Gao, Z.; Wang, C.; He, W. Effect of a novel phosphate on the flotation of serpentinecontaining copper-nickel sulfide ore. Miner. Eng. 2020, 150, 106276. [CrossRef]

36. Li, Y.; Wang, J.-K.; Wei, C.; Liu, C.-X.; Jiang, J.-B.; Wang, F. Sulfidation roasting of low grade lead-zinc oxide ore with elemental sulfur. Miner. Eng. 2010, 23, 563-566. [CrossRef]

37. Guo, Z.; Zhu, D.; Pan, J.; Wu, T.; Zhang, F. Improving Beneficiation of Copper and Iron from Copper Slag by Modifying the Molten Copper Slag. Metals 2016, 6, 86. [CrossRef]

38. Selivanov, E.N.; Gulyaeva, R.I.; Zelytin, D.I.; Belyaev, V.V.; Selmenskich, N.I. Influence of cooling speed on slag structure from smelting of copper-zinc concentrates in vanyukov furnace. Tsvetnye Met. 2009, 12, 27-31.

39. Day, J.M.D. Siderophile Elements: Systematics and Significance. In Encyclopedia of Geology, 2nd ed.; Alderton, D., Elias, S.A., Eds.; Academic Press: Oxford, UK, 2021; pp. 52-66.

40. Aulbach, S.; Giuliani, A.; Fiorentini, M.L.; Baumgartner, R.J.; Savard, D.; Kamenetsky, V.S.; Griffin, W.L. Siderophile and chalcophile elements in spinels, sulphides and native $\mathrm{Ni}$ in strongly metasomatised xenoliths from the Bultfontein kimberlite (South Africa). Lithos 2021, 380-381, 105880. [CrossRef]

41. You, J.; Hong, S.-H. Densification mechanism and microstructure development of Fe-Ni alloys consolidated by field assisted sintering. J. Alloys Compd. 2021, 884, 161102. [CrossRef]

42. Khoso, S.A.; Gao, Z.; Tian, M.; Hu, Y.; Sun, W. The synergistic depression phenomenon of an organic and inorganic reagent on FeS2 in CuS flotation scheme. J. Mol. Liq. 2020, 299, 112198. [CrossRef] 